\title{
Leveraging Experiential Learning to Incorporate Social Entrepreneurship in MBA Programs: A Case Study
}

\author{
Amrou Awaysheh, Drew Bonfiglio
}

\begin{abstract}
:
Social entrepreneurship in business education is growing in importance as a way to teach ethics and instill high ethical standards in individuals. One effective way to integrate social entrepreneurship is through experiential learning; where the participant is actively involved in processing the knowledge and developing skills, while being involved in the learning situation. MBA programs are currently beginning to incorporate social entrepreneurship into their curricula to teach their students, as well as developing students' intercultural skills. An examination of the current trends will be followed by an analysis of how business schools can effectively incorporate social entrepreneurship into the MBA curriculum. To tie these concepts together, the paper provides a case study of a program run by Emzingo, a leadership development company, and IE Business School. The reasons for the in-depth case study are three-fold. First, it provides an example of how business schools can use experiential learning to incorporate social entrepreneurship in an international context. Second, it highlights the benefits of incorporating social entrepreneurship in MBA programs. Finally, it provides a general framework for business programs that are looking to integrate various social entrepreneurship elements in their MBA programs.
\end{abstract}

\section{INTRODUCTION}

The landscape in business is changing, and business schools have to adapt. There has been a shift from a focus on just improving shareholder value and into improving the welfare of all stakeholders. Porter and Kramer (2011) identify the factors that are impacting our current market economy: "Capitalism is under siege....In recent years, business increasingly has been viewed as a major cause of social, environmental, and economic problem...[but] the solution lies in the principle of shared value, which involves creating economic value in a way that also creates value for society by addressing its needs and challenges. Businesses must reconnect company success with social progress.” For myriad reasons, business leaders in every country around the world are 
finding that Corporate Social Responsibility (CSR) is an inescapable priority (Porter and Kramer, 2006). To keep up with the needs of the corporate world, business schools are incorporating various CSR issues into their curricula to remain relevant and continue to prepare students to enter a business world where knowledge and skills gained from exposure to these issues will be valuable. Companies are recognizing the interdependent nature of the relationship between business and society. One of the elements that can help students understand the relationship between business and society is social entrepreneurship. Business schools are using social entrepreneurship as one avenue to help students get exposure to issues that are relevant to the concept of shared value and demonstrate the interplay between market forces and social forces of good. Social entrepreneurship is part of the curriculum at leading business schools and is the subject of many professional and academic meetings (McLean and Peredo, 2006). This paper discusses the effectiveness of using Experiential Learning as a learning method in the context of social entrepreneurship within the MBA experience. Next, the paper discusses why business schools are including social entrepreneurship in the curriculum, the advantages and benefits the schools and students expect from these programs, and the ways in which these programs are being implemented. Finally, these concepts are brought to life through a case study focused on an experiential learning program that Emzingo Group and IE Business School provide for MBA students. This case study examination of Emzingo group is an opportunity to retain the holistic and meaningful characteristics of reallife events (Yin, 2009). The case study provides the reader with an opportunity to understand how social entrepreneurship can be integrated into management curricula through experiential learning. Second, it identifies some of the benefits of incorporating experiential learning in MBA programs. Third, some of the important elements of the case study are presented in helping educators in how some components can be used in programs that are looking to integrate social entrepreneurship in 
their MBA programs. Finally, this case study is in a setting that helps enhance the participants' intercultural skills.

\section{The Changing Business Landscape}

\subsection{Social Entrepreneurship}

For several decades, social entrepreneurship and social business have existed in various forms. The practice of integrating social and economic value creation has a long heritage with a global presence (Mair and Marti, 2006). The definition of Social Entrepreneurship has many elements that detail the development of such ventures (Pomerantz 2003), the value they create to society at large (Phills, J., 2008), and the benefits they bring to marginalized society members (Martin and Osberg, 2007). Whether one believes business characteristics need to be incorporated into the model, the undertaking is for- or not-for-profit, if an individual or an organizations designs the solution, or if the solution is innovative or not are some of the dimensions on which this topic is debated. With this in mind, and rather than focusing on the definition. We will use the context in which business schools tend discuss entrepreneurship, we will use Ashoka's (2012) definition: “Social entrepreneurs are individuals with innovative solutions to society’s most pressing social problems. They are ambitious and persistent, tackling major social issues and offering new ideas for wide-scale change.” Some popular examples of successful social entrepreneurship are Professor Muhammad Yunus’s Grameen Bank and Dr. G. Venkataswamy’s Avarind Eye Hospital, both established in 1976.

By their inherent operating business models social entrepreneurs have to juggle a number of (sometimes) competing dimensions. In addition to the regular business dimensions that entrepreneurs have to deal with, such as customers, suppliers, and competitors; social entrepreneurs have to address issues of the community at large and how their business contributes 
to the greater social good. However, these skills provide managers with the tools, training, that can be leveraged outside the social business and lead to success in traditional businesses. Therefore, while non-profits only contribute $10 \%$ to the US GDP, non-profits can provide a platform for training business managers and the skills gained through social entrepreneurship programs can be used to allow managers to have a powerful impact.

\subsection{Experiential Learning}

The concept of experiential learning has been around for many decades. Its roots can be traced back as far as 400 B.C. to the often cited Sophocles quote, "One must learn by doing the thing for though you think you know it - you have no certainty, until you try” (Gentry, 1990). However, much of the more recent theory is related to Dewey's “theory of experience” (Dewey, 1938). This theory was built on by Kolb’s (1984) 4-stage Experiential Learning (EL) model. The four stages of Kolb's model are first, individuals learn from concrete experience, which leads to reflective observation on that experience. The third stage is the development of theory through abstract conceptualization. Finally, the theory is tested through active experimentation, which leads to new concrete experiences and perpetuation of the cycle.

EL has been the subject of much research and its effectiveness as a learning methodology has been validated (Yamazaki and Kayes, 2004). Additionally, activities associated with experiential learning have been shown to increase an individual's systemic knowledge as well as tacit knowledge (Rashford and Neiva de Figueiredo, 2010). When participants have the opportunity to live what they are learning and experience the concepts in real life, through EL for instance, they will have memories that will last for much longer.

EL is a way to fill the gap between explicit and tacit knowledge (Honig 2004), which can be a very valuable tool in MBA programs. Experiential learning can be used to help students learn 
managerial skills that can help them lead teams through unknown territory, and provides them a safe environment to make mistakes and learn from their mistakes. This can be especially valuable in graduate business programs whose students are typically older, and can benefit more from the experience (Marsh, 2013). Thus, EL can be used effectively in business school curricula to cement the learnings that students experience in their program.

Kolb and Kolb (2005) suggest that effective learning needs to create space for feeling and thinking, acting and reflecting, and allowing learners to take charge of their own learning, all of which can be done through experiential learning. Specifically, in reference to higher education, proponents of experiential learning as a learning process believe that it is an effective method, considering the other types of learning students have available in this setting. Students in such programs already participate in classroom learning experiences, group work, extracurricular activities, and individual projects. Experiential learning adds another dimension to the structure already found in institutions of higher learning as it can further help enhance students’ learning.

At its core EL has six propositions that are accepted by all EL scholars. First, EL is not related to certain or specific outcomes, learning should be considered as a process. Second, to truly ensure that students learn, they need to relate everything to what they have learned before, in essence, relearning. Third, learning requires the resolution of conflict, the learning process requires reflection and action in the mind of the student to allow some conflict to be created in the students mind so that it may be resolved. Fourth, learning is not just cognition, but the student must integrate total functions such as thinking and feeling about the concept. Fifth, learning is the result of transactions between the student and their environment. Finally, learning itself creates knowledge as social knowledge is created and then recreated by the student (Kolb and Kolb, 2012). 
A well-designed experiential learning program should force students to draw from a broad range of topics covered in the MBA curriculum and from their previous work experience. This can include more technical courses like operations or strategy, others like business ethics and leading in teams, and the inclusion of some element of organizational development (Rashford \& Neiva de Figueiredo, 2010). Two direct outcomes of implementing EL is that this type of learning activity gives students an opportunity to link theoretical knowledge and its application. Bridging the gap between theory and reality has been a goal of professional business education since its beginnings; and experiential learning is one powerful practice that helps students transfer the acquired theoretical knowledge into actionable application. Secondly, EL prepares students for future "realworld” situations which they will face after the MBA. Experiential learning helps students break out of a functional silo.

There are four stages of the EL model as described by Kolb and Kolb (2012). These four stages are Situation Analysis, Problem Analysis, Solution Analysis, and Implementation Analysis. Situation analysis is where the learner examines the context to determine what the issue is and what they need to address all of the issues. Learners in this stage need to function in an unstructured scenario to try and use their intuition to find a solution for the problem. In the Problem Analysis stage, the learner tries to identify the specific factors that are the root causes of the problem. This requires the learner to think critically of the problem and reflect on the causes. The third stage is solution analysis, here the learner identifies all of the different solutions that could be put in place. To be successful in this stage, the learner needs to be able to take abstract ideas and transform them into an action plan numerically compare them. Finally, the fourth stage is implementation analysis, here the goal is to set in place an action plan and ensure it is carried out. Learners here need to ensure that they are able to work well with others to help them execute the best solutions. 


\subsection{Intercultural Skills}

One of the benefits of EL is to experience opportunities that push participants outside their comfort zones. It allows them to cement learnings that are difficult to learn through "standard" methods. One growing important tool that is needed from managers is intercultural skills (Bedwell et al., 2014). These skills are becoming much more important in an ever-globalized workplace. Managers are expected to be able to deal with people in a number of different environments and from a different set of cultures. These intercultural skills help managers interact with their managers both within their organization and outside. These skills are thus an important aspect of managers that need to be fostered and enhanced. Strong intercultural skills are very important as they enhance the companies' abilities to be more successful in an international context. As managers go "internationally" and become expats, having a strong intercultural skillset increases their likelihood of success. (Charleston et al, 2017).

However, there are no longer "international" managers, many managers now need to interact regularly in an international context regardless of where they are based (Ramllal and Ramlall, 2016). The need to have a strong set of intercultural skills have become integral in the success of any manager. However, due to the complicated nature of the topic itself it is difficult to educate managers on intercultural skills. Thus, there are a number of options that management educators can go through so they can enhance intercultural skills (Taras et al, 2013). These innovative techniques can be used to enhance managers' intercultural skills and increase the likelihood of their success in an ever-globalizing workplace.

\section{BUSINESS SCHOOL - WHERE SOCIAL ENTREPRENUERSHIP AND EXPERIENTIAL LEARNING [SHOULD] COME TOGETHER}




\subsection{Understanding the current landscape - Current MBA program offerings}

There are 786 AACSB-accredited business schools in 53 countries (AACSB, 2016). To get a better understanding the research team examined MBA programs that appear in the FT rankings (Financial Times, 2017). We focused on the programs that appear in the top 100 in the last decade. We looked at any program that appeared at least twice in the rankings between 2007 and 2017. This is not to say that these programs are better than others, rather the research team used this as a filter to identify MBA programs that are larger and thus have the capacity to integrate social entrepreneurship. It would be expected that these larger programs are also closer to a larger number of recruiters and thus are better able to react to recruiters and what they need. These business schools would thus be actively involved in preparing their MBA graduates for the market place, ensuring they have the skills that MBA students desire and MBA recruiters expect.

Today's typical full-time MBA program is structured around three key areas: core courses, elective courses, and extracurricular activities including professional and social clubs as well as immersion and business consulting experiences. Many of schools have the same types of core courses that are then complemented with electives, which vary greatly by school, with some like Columbia Business School offering over 200 electives (Columbia University, 2011). Giving students the opportunity to customize their curriculum and learn about the topics that most interest them. Most of the core and elective courses are traditional, classroom-based learning. Finally, some MBA programs offer opportunities beyond classroom learning, as they try to enhance all of managers' skills to understand various cultural issues (Tuleja, 2008). Such programs try to enhance students' intercultural skills by immersing students in various locations. Exchange programs, social clubs, sports clubs, internships, and real-world learning projects give students the opportunity to challenge themselves outside the classroom, learn about business abroad, network with classmates 
outside of their cohort/section, and explore new business opportunities. These international experiences enhance the learning and allow students to gain experiences that help enhance intercultural skills (Taras et al, 2013).

\subsection{The case for Responsible Management Education}

Overall, MBA students have incredible and diverse learning opportunities. Despite this array of opportunities, there are many critiques of MBA programs. One point of view is that there is an overemphasis on analysis at the expense of wisdom, leadership and interpersonal skills and that there is not enough practical experience (Pfeffer \& Fong 2002). There is also much discussion on the method of instruction, some schools lecture, others teach by the case method, some use a combination. But in relatively few instances in established business schools is there much clinical training or learning by doing--experiential learning where "concrete experience is the basis for observation and reflection" (Kolb, 1976). Students learn to talk about business, but it is not clear they learn business. There is an argument that management is a professional trade, a craft to be honed through practice and experience, not in the traditional classroom, as "true managing” cannot be replicated in the classroom (Mintzberg \& Lampel, 2001). Company recruiters continue to assert that MBA programs could be more relevant by doing more to inculcate "soft skills" such as leadership, communication, and interpersonal skills (Eberhardt, McGee, \& Moser, 1997)

Another often cited area of improvement is in how MBAs contribute to society. MBA programs face intense criticism for failing to impart useful skills, prepare leaders, instill norms of ethical behavior, and even lead graduates to good corporate jobs (Khurana, 2007). The entire MBA curriculum must be infused with multidisciplinary, practical, and ethical questions and analyses reflecting the complex challenges business leaders face. These criticisms are from across the 
spectrum of business school stakeholders: students, recruiters, alumni, faculty, and society at large (Bennis and O'Toole, 2005).

If business schools are to regain their relevance, they must come to grips with the reality that business management is not a scientific discipline but a profession, and they must deal with what a professional education requires. Business schools are not ignoring these criticisms and observations and they are constantly revamping their programs and curricula. There are continuous changes made to programs, one of which is the incorporation of social entrepreneurship. One of the ways this can be advanced is through the Principles for Responsible Management Education (PRME), whose goal is to inspire and champion responsible management education. The PRME strives to accomplish this objective by incorporating sustainability and corporate responsibility in the mainstream business education. The PRME steering committee includes the UN Global Compact, the Global Responsible Leadership Initiative, Net Impact, the AACSB, and GMAC. By including such prestigious institutions that value responsible management and the AACSB, credence and external validation is given to the PRME as well as the ability to ensure that it is widely accepted and valued by business schools and eventually be incorporated as part of business school curricula.

It is reasonable to assume that the majority of business school graduates, regardless of their chosen industry or sector of interest would benefit from the ability to navigate uncertainty, improved listening skills, the ability produce results with limited resources and work with a variety of stakeholders, and many of the other skills identified earlier. The PRME advocates for many different elements of responsible management, and one such important element is the incorporation of social entrepreneurship into the MBA curricula. Notably, social entrepreneurship 
in its practical, applied form that will described in the case study later in this paper address the applied learning, and social, ethical, and leadership gaps that currently exists in MBA education.

\subsection{Student and Employer Demand for Social Entrepreneurship Experience}

In the U.S. alone, there are over 4,000 MBA programs offered by 454 institutions (AACSB, 2010). Over time these programs have evolved. Among MBA programs is the shift in student expectations and desires upon graduating from a MBA program. Business and academic publications have recognized that a significant portion of business school students are no longer after the finance and consulting positions typical for MBA graduates. One study reveals that almost half of the student population (45\%) would take a $15 \%$ pay cut "for a job that makes a social or environmental impact” (Net Impact, 2012). This subset of the student population wants to learn how to run companies with both higher growth and higher impact (Jones, 2011).

Some students come to business school with entrepreneurial aspirations and many individuals are creating ventures that use a business-model approach to solve social problems (Sullivan, 2011). To support this trend from the curriculum side, some schools are emphasizing creativity and how to adapt their business models to consider social and environmental results as well as financial ones. Schools are also modifying their curricula to focus on responsible decision making in business and to look deeper into the social and environmental context in which businesses operate (Aspen Institute Center for Education, 2009). This modification also responds to the marketplace as recruiters are looking for students that have an MBA education that integrates sustainability issues.

This when combined with other business-school stakeholders expecting more from MBA graduates, makes a very strong case for integrating more responsible business education elements in MBA programs. 


\subsection{Social Entrepreneurship}

Social entrepreneurship a burgeoning field that is now - under the umbrella of sustainability - an important element of responsible leadership education (James and Schmitz, 2011). The incorporation of social entrepreneurship into the curriculum is a very important component of the adjustments business schools are making to meet the needs and demands of students and of the employers of their MBA graduates (Singh \& Wise, 2010). This is a necessary step given that social entrepreneurship and social innovation are increasingly recognized as crucial domains for management educators (Tracey \& Phillips, 2007).

As noted earlier, one of the main drivers for business schools to bring social entrepreneurship into the fold is their clients' - potential students' - demand for these types of opportunities. This is not unique to the students currently attending business school. It is also a theme among prospective students. The availability of social entrepreneurship related opportunities is now an influencing factor for some students when deciding on which business school to attend. Membership in Net Impact - a global organization comprised of green-minded [and socially inclined] MBA students and professionals, has more than tripled in the last few years. This is an important draw for prospective students. Additionally, more and more applicants from non-profits and social enterprises are entering business schools to learn skills and competencies to build sustainable businesses (Lawrence et al., 2011). Interest in social entrepreneurship and innovation among business school students is evidenced both by the growing number of social enterprise student societies, and by the fact that social entrepreneurship business plan competitions are now commonplace in many universities (Olszak and Sidorick, 2003). Business schools must adjust their recruiting tactics, marketing messages, and on-program opportunities to attract this new wave of professionals coming from or heading into social entrepreneurship and the social sector. 
The trend towards incorporating more social and environmental issues into the MBA is not brand new. It has, however, been amplified by the financial crisis, BP oil spill in the Gulf of Mexico, the Madoff Ponzi Scheme, a series of insider trading activities, and the unethical behavior from the likes of Wal-Mart, FIFA, Volkswagen, and others. Aspen Institute notes that "more and more business schools are heeding the call to prepare their students to be...social stewards and ethical actors in the workplace” (Aspen Institute Center for Education, 2009). In fact, business school students have been leading this initiative and signing ethics oaths which was driven, for many, by "their personal values and the current economic climate" (Harvard Crimson, 2009).

Popular business and news publications are also pointing to this new trend among MBA students. "The notion of using a management degree to do good while doing well has grown in popularity on today's business school campuses, where an ever-increasing number of students plan on putting their business savvy to use within the nonprofit sector. The recession has led many applicants to reevaluate their priorities and determine what they want to do with their lives, often trading jobs with status and hefty paychecks for careers with a positive social impact” (Blackman, 2011).

The government and businesses themselves are making moves on this front as well. There is significant attention being paid, on and off campus, about the new business designation in the U.S., the Benefit Corporation or B corp. A B Corp is a firm that "must have an explicit social or environmental mission, and a legally binding fiduciary responsibility to take into account the interests of workers, the community and the environment as well as its shareholders. It must also publish independently verified reports on its social and environmental impact alongside its financial results” (The Economist, 2012). Companies, large and small, including the likes of Patagonia and Ben and Jerry's, have already joined the B-Corp party. However, it is important to note that there are some criticisms of the overall state of incorporation laws in the USA. This 
criticism can be levied at B-Corp's as well. Overall, the incorporation laws in the USA, both at the state and federal levels are not as strong as could be. There are a lot of gaps that exist in who is held responsible for unethical actions within a corporation and the accountability of senior managers. This lack of accountability exists to shareholders in general. Needless to say, this lack of accountability is further exacerbated when one considers other stakeholders. Stronger accountability for corporations will ultimately enhance a firm's treatment of all the stakeholders.

\subsection{Current state of Social Entrepreneurship in graduate programs}

Entrepreneurship as a general field of study has been part of business school programs for some time, but how to teach and develop individuals who take on the unique challenge of creating a business that has both social and commercial objectives is omitted (or at least it was for quite some time) (Tracey \& Phillips, 2007, p. 265). The trend has changed over the past decade. Each of the top 20 MBA programs in the world has incorporated social entrepreneurship into its curriculum and many other business schools have followed this trend. It is important to note one caveat - most of the SE initiatives are not part of the core curriculum and requirements for all students. That being said, all have social entrepreneurship programs, centers for social entrepreneurship/enterprise, fellowships, electives, or competitions focused on SE. All Top 20 schools have a Net Impact chapter and nearly all have electives in social entrepreneurship. In the US, there are over 160 business schools with Net Impact chapters. In addition to the reasons identified earlier, MBA programs continue to develop these components of the curriculum because of the "blurring of the distinctions between business, nonprofit and government organizations...[which has] created an opportunity for leading business schools to have significant social impact by constructively exploring the adaptation of business” (Duke University, 2011). 
One such example is Yale University's Program on Social Enterprise (PSE), which, "supports scholars, students, alumni, and practitioners interested in exploring the ways in which business skills and disciplines can be harnessed to most effectively and efficiently achieve social objectives" (Stevens, 2011). A second example is NYU-Stern which has an International Social Impact Strategies course where students travel to India to see social entrepreneurship activities first hand. Stern has found that, "Interest in social entrepreneurship has exploded in recent years" (Byrne, 2010). It is evident that the top business schools are making a concerted effort to incorporate social entrepreneurship. Such programs enhance the ability for future faculty to be well-rounded, and well-versed in social entrepreneurship and the social impact of the firm (James and Schmitz, 2011). For additional details on what top programs are doing on the Social Entrepreneurship front, Appendix 1 provides an in depth examination of social entrepreneurship activities, and “experiential learning” programs related to SE at the top 20 business schools. Again, it is important to point out that the current state is not limited to any sort of "top" list. Schools all over the rankings are seeing similar trends and you can find students from hundreds of programs participating in Net Impact, attending Social Investment conferences, and finding ways to connect business education to entrepreneurship, social impact, or both.

\section{Effective ways for Business Schools to Incorporate SE into their Programs}

After laying down the foundation of why Social Entrepreneurship is important to managers and thus an integral part of management education,we will now focus on "how" schools can most effectively incorporate SE into the curriculum. Experiential learning is an excellent mechanism for business schools to incorporate social entrepreneurship into the curriculum. This is different from the majority of other learning activities currently taking place at business schools. Schools can then focus on the "experience," which has inherent benefits for learning and provides an 
alternative to classroom learning (Boud, Cohen, and Walker, 1993). We aim to fill the gap in current academic literature by connecting experiential learning and social entrepreneurship. Our study also presents an excellent opportunity to discuss the benefit of intercultural skills. Social issues and social entrepreneurship are and will continue to be important to incorporate into MBA programs, and how business schools can integrate them into their MBA programs is just as important.

\subsection{Applying Experiential Learning}

Business schools are very good at challenging students, but, unfortunately, business schools and educational institutions in general, have not been as successful in providing the support that should accompany the challenge in order to create an ideal learning environment (Kegan, 1994). Experiential learning programs can help institutions to improve the type of support students receive during their journey as MBA students. Kolb and Kolb (2005) suggest that effective learning needs to create space for feeling and thinking, acting and reflecting, and allowing learners to take charge of their own learning, all of which can be done through experiential learning. Many times students in business schools continue to think about free and efficient markets and how they contribute to wealth creation and the overall betterment of society. However, other viewpoints and challenges to this view are rarely examined in depth. By considering social entrepreneurship students will be able to learn and consider other viewpoints and perhaps understand instances where the free and efficient market doesn’t operate as ideally as expected.

Proponents of experiential learning as a learning process believe that it is an effective method, specifically in a graduate academic setting. Students in such programs already participate in classroom learning experiences, group work, extracurricular activities, and individual projects. Experiential learning adds another dimension to the structure already found in institutions of higher 
learning. Getting students to go beyond the classroom is critical and, recognizing that there is a lot of learning that happens in the interaction between the individual and the external environment (Beard \& Wilson, 2002), schools can leverage this to build interesting, meaningful programs within the MBA program that incorporate social entrepreneurship. A variety of activities and methodologies have potential to be effective experiential learning opportunities. These activities many of which schools are already using -range from lab and experimental exercises, to case studies, to group assignments, to simulations, and more.

In particular, internships and live cases are most important for business schools to consider because these are the most likely activities to meet all of the criteria for a beneficial experiential learning activity (Gentry, 1990). A well-designed experiential learning program should force students to draw from a broad range of topics covered in the MBA curriculum and from their previous work experience. As mentioned earlier, this can include more technical courses like operations or strategy, others like business ethics and leading in teams, and the inclusion of some element of organizational development (Rashford \& Neiva de Figueiredo, 2010). We add emerging course offerings in CSR, Sustainability, and Social Entrepreneurship to the list. Having these internships in an international context is even more valuable for students as it enables them to experience more things and learn a number of things, including intercultural skills (Gannon et al, 2016).

As we show in the case study section of this article, to provide such a unique opportunity during the MBA program is incredibly valuable for the student learning experience and, in fact, does force students to apply knowledge from both the MBA and their previous professional experiences. There are two very strong arguments for why MBA programs should use experiential learning in their curriculum. First, this type of learning activity gives students an opportunity to link theoretical knowledge and its application. Bridging the gap between theory and reality has been a 
goal of profession business education since its beginnings and experiential learning is one powerful practice that helps students transfer the acquired theoretical knowledge into actionable application (Rashford \& Neiva de Figueiredo, 2010). Second, experiential learning prepares students for future "real-world" situations which they will face after the MBA. The case-method, which many business schools have adopted, usually emphasizes one functional area. Experiential learning helps students break out of a functional silo. Both tacit and systemic knowledge are enhanced through “learning by doing” activities (Rashford \& Neiva de Figueiredo, 2010). To help contextualize these points, Table 1, identifies the six ways to educate social entrepreneurs (Tracey \& Phillips, 2007) and compares them to the specific types of experiential learning activities business schools can implement under these six umbrellas. These components are supported with evidence from a current example in the following section.

The following section describes the partnership between IE Business School and Emzingo. This serves as a case study to discuss the benefits of a social entrepreneurship based experiential learning opportunity. We believe this program is an important contribution to the field of experiential learning in higher education, especially because the aforementioned "support" that is currently missing from many MBA offerings is compensated through the use of coaching, guided reflection, and mentoring during the experiential learning example and because it incorporates each of the four steps of Kolb’s (2004) model: learn from concrete experience, reflect on this experience, create a theory based on this experience, and test the theory to perpetuate the cycle.

\section{IE BUSINESS SCHOOL AND EMZINGO PARTNERSHIP - A CASE STUDY IN SOCIAL ENTREPRENEURSHIP AND EXPERIENTIAL LEARNING}




\subsection{Case Study}

In 2010, IE Business School and Emzingo Group, a leadership development company, partnered to provide an innovative new program which puts social entrepreneurship, social enterprise and social impact at the forefront of the MBA experience for a select group of International MBA students. The program has gained momentum and IE Business School and Emzingo Group LLC have continued to work together to provide a group of IE's International MBA students with a unique internship opportunity. It has components of social innovation and social entrepreneurship built into the 6-8 week experiential learning program that provides the students internship or elective credit. The two main components of the program are: a consulting project and a leadership development curriculum. Students are assigned in teams of 2-3 to consult for social entrepreneurs, social enterprises, and NGOs. In parallel to the project work, the students complete a leadership development curriculum consisting of classroom-based sessions, immersion activities, facilitated discussions, coaching, and reflection. After a lengthy examination of the current offerings that MBA programs have in place. A group of MBA graduates came together to found Emzingo to help enhance program offerings. Emzingo provides a turn-key solution that includes project development, operations and logistics, and the majority of curriculum activities.. As part of the partnership, the partner schools provides administrative support and partial financing student financing. Figure 1 provides a simplified overview and summary of the Emzingo program.

This case study serves as a resource for other institutions that are considering creating their own experiential learning and social entrepreneurship programs. Emzingo Group has grown to partner with other business schools and has hosted students from Princeton University, UVA, Leeds University, London School of Economics, ESADE, IESE, McGill, and Georgetown University. The flagship program for Emzingo is its NexGen program - as the company calls it - which has 
graduated over 300 MBA and Master's students. This opportunity is a low-risk, high-impact way for business schools to provide a select group of students with an experiential learning program revolving around social entrepreneurship. An overview of the program structure, financial model, faculty involvement, project examples, and other details are described in the following sections. But beyond Emzingo, the paper provides a detailed description of how a business school can choose to implement this into their program.

\subsection{Program Structure}

As mentioned earlier, Emzingo Group runs programs with a number of business schools. But for the purpose of this paper, we will use the relationship between Emzingo and IE Business School (IE) as the primary example. The program at each of the universities is partially customized for their own university, however, the major elements all remain the same. At IE, students are required to complete a lab period. Emzingo and IE offer Emzingo's NexGen program to between 15 and 25 students for each intake (twice per year). The program is highly sought after and increasingly selective. Therefore, students who apply must complete three evaluative rounds during the application process and must be selected by Emzingo and meet certain IE requirements in order to participate. The program consists of three phases: orientation, core (“in-country"), and reintegration. After completing the program, students are graded on two formal deliverables they must provide: a personal reflection statement and a project report. The experience, including these deliverables, gives these students course credits which are applied toward graduation like any other course.

The relationship between Emzingo and IE is designed around collaboration in three areas: administrative, financial, and educational. On the administrative front, the two organizations work together to promote the opportunity to the student body, complete a rigorous recruiting- 
application-interview process of the student applicants, coordinate communications and media relations (including a post-program presentation that staff and the student body at-large are invited to), and coordinate any other logistics items such as classroom reservations for training sessions. Emzingo's business model is based on contributions/program fees from IE, the participating students, and the partner organizations for which the students consult. The third area of of collaboration is educational: IE is focused on integrating social impact into its student experience overall and therefore ensure that the learning objectives and outcomes from the Emzingo experience align with their organizational ethos, values and curriculum.

\subsection{Program Content}

Emzingo is a social enterprise that was created in early 2010. It uses social impact projects and a leadership development curriculum as vehicles to transform individuals and create the next generation of responsible leaders. The organization is essentially a turn-key solution provider for a hybrid leadership development-social impact-professional development program. IE and other academic partners find value in providing a unique experience for a select group of students that aligns with each institution's values and educational focus areas. Students who participate are able to apply their professional skills and the concepts learned during the MBA in a new and challenging environment. They are also provided with over 70 hours of training and development which complements the MBA coursework. Students apply this training in an international setting, which also allows them to develop and improve their intercultural skills. Resulting in managers that are more responsible, well-rounded with enhanced intercultural skills, and understand the intricacies of social entrepreneurship.

The program begins with a 5 - 7 day orientation period; Emzingo staff and partners, guest lectures, and cultural immersion experiences cover topics ranging from sustainable development to 
intercultural skills to teambuilding to economic analysis of South Africa, Peru, or Brazil (where the core phase of the program takes place) ${ }^{1}$. For the purposes of this example, we will talk about the South African program. During orientation, as well as during the remainder of the program, the content of all sessions and project work fall under five focus areas which Emzingo and IE believe are critical for the next generation of responsible business leaders to understand. They are sustainability, innovation (including social innovation) and change, emotional intelligence and self-awareness, global management and cultural awareness, and LeaderSHIFT - Emzingo's leadership philosophy that challenges responsible business leaders to re-assess traditional business paradigms.

Once the students complete the orientation and begin their project work in South Africa they are fully and immediately immersed. For the next six weeks, students spend four business days per week consulting in teams of two or three on-site with the social sector partners. Prior to arriving in Johannesburg, Emzingo has already developed the scope of the projects with the social enterprises, entrepreneurs and NGOs. The projects are all business related such as a marketing plan, five-year business strategy plan, or operations assessment. The objective is to provide an opportunity for students to apply the skills they have learned during the MBA program directly to projects that are critical to the long-term success of the social sector partners.

In addition to the project work, participants in the NexGen program continue the leadership development curriculum that began during their orientation. . They attend classroom sessions at

\footnotetext{
${ }^{1}$ Emzingo has found that with a diverse, international group that has spent a significant time in Madrid, which is also where their classmates will continue to live while they participate in the Emzingo program, it is more effective to immerse students in an international location rather than run the program locally. This is not the central focus of the paper, but a consideration for other organizations interested in running such programs. This additional element further enhances the inter-cultural skills that the students learn. However, the partnership is experimenting with local offerings to made exposure less expensive for potential participants and universities.
} 
local business schools, meet with industry professionals in related fields, and engage in facilitated discussions and reflective exercises that touch upon value creation and the triple bottom line (i.e. considering social, environment, and financial impact in business), corporate social investment, responsible leadership, and self-awareness. While in South Africa, these sessions are held approximately two evenings and one business day per week. Including orientation and the core program in South Africa, students complete between 70 and 100 hours of classroom sessions, facilitated discussions, immersion activities, and reflection sessions.

At the end of the sixth week in-country, students present their deliverables to the social sector partner and all other relevant stakeholders. For the next two weeks after this presentation, the students work virtually on two activities. First, the students must submit a formal, electronic version of their final deliverable to the social sector client-partner, which includes any modifications and updates suggested during the final presentation. The second activity is reflection paper. One major objective of this second deliverable is to require students to reflect on their personal experiences and allows them to elaborate on their cultural learnings from being based in both Spain and South Africa. The following section will provide an overview of some of the previous projects.

\subsection{Consulting Projects}

After arriving in South Africa, students spend six weeks working on consulting projects. This section describes some of the consulting projects that were conducted in South Africa. Examples of past projects include a marketing plan for a small community based non-profit called Kliptown Youth Program (the founder is a 2012 CNN Hero nominee), operations improvements for the Branson Centre of Entrepreneurship, financial management and planning for an international NGO, Action Aid, a business plan/business model design for Bean There, a fair-trade coffee 
company, and a number of strategy projects for several different types of organizations, among others.

To further illustrate the type of projects students take on, here is an example project between Emzingo Fellows and The Hub - Johannesburg. The Hub in Johannesburg is a for-profit social enterprise. Its aim is to be “a modern habitat for social and innovative entrepreneurs, providing opportunities to inspire, support, incubate, learn and collaborate.” The Hub shares space with other entrepreneurs - to conduct learning journeys, workshops and learning tools to event hosting of up to 150 people. With this organization's wide range of services, it is challenging to understand and manage all of the relevant clients and stakeholders. To assist with this effort, Emzingo Fellows worked with The Hub-Johannesburg's founder, Lesley Williams (who was one of South Africa’s 2011 Top 200 Young People as named by Mail \& Guardian newspaper), to meet this challenge. During the Emzingo program, the MBA students applied a variety of lessons learned at IE and in their professional careers to assess the current offerings of the organization. The Fellows analyzed the various services provided, talked with current Hub clients, interviewed relevant stakeholders and potential Hub members, and evaluated the organization's current brand. Always keeping in mind that the objective was to increase The Hub-Johannesburg's revenue while remaining true to its ideals and social goals, the students created a strategic plan for working with existing clients and approaching new clients; generated a branding, marketing and communications plan; and provided tangible, immediately useable marketing materials. After this experience, it was evident that both the organization and the Fellows had benefited significantly. One Fellow told Emzingo that she “realized that I had learned things on the MBA that I didn’t know I had... It helped me put what I learned on the MBA into practice and really it has given me confidence in my own abilities.” This participant went on to say that the experience inspired her to try and change the world when 
she takes on whatever is next in her life after graduate school. She specifically cited how she was able to enhance her intercultural skills by working on an international project, in an international context, with an internationally diverse team and client. She has since launched her own marketing company, including work on CSR marketing and personal branding. The second IE student working on this project was equally inspired and believes it was the best experience of the MBA and, according to her is “Emzingo’s number one fan”. She went on to join Unreasonable Institute where they "get world-changing entrepreneurs what they need to scale their impact" and where this Emzingo alumnae applied her business and social sector experience every day. On the client/partner side, The Hub founders agreed that it was a valuable experience and that with very limited resources and guidance the Fellows were able to create meaningful recommendations and solutions that will help The Hub-Johannesburg better meet clients’ needs and understand the organization's value propositions to these clients as it entered its second year of business. In this case, the students clearly were able to leverage the marketing and strategy courses they took at IE as well as perform stakeholder analysis for each of the services provided by The Hub.

\subsection{Program Perception}

To get a better understanding of the program, the research team was involved in interviewing participants from the Emzingo program, members of the Emzingo team, as well as faculty from IE. We also reviewed all of the exit surveys that program participants completed at the end of the program. This program is, as one participant put it, "an opportunity to explore and understand a previously unknown situation in order to make an impact and make informed personal and business decisions in the future.” For another participant, “the experience [was] a constant eyeopener...I was truly amazed at how many inspiring people I met.” Yet another participant stated that the experience rejuvenated his passions, one of which is doing work with a social impact. 
Several students went as far as saying this experiential learning program was "by far" the best part of the MBA. Emzingo and IE have shown that experiential learning in business school is an effective way to incorporate social entrepreneurship into the curriculum.

From surveys and focus groups conducted among Emzingo alumni, communication skills, the ability to work across cultures, and improved self-awareness and emotional intelligence were identified as the most highly impacted competencies. Looking at over three years of post-program surveys to Emzingo Fellows, 100\% of respondents agreed that the program improved/positively influenced project management skills, the ability to manage diverse stakeholders, the ability to create a collaborative environment, and their leadership skills. In the same survey, $90 \%$ of respondents found improvement in self-awareness and emotional intelligence, client relationship management skills, and the ability to incorporate social and environment impact into business management. This group of students stated that the program was "a great start for aspiring students" and "an opportunity to implement classroom skills in the real world.”

Additionally, $100 \%$ of all 78 Fellows surveyed, across all programs, which spans seven NexGen programs, would recommend Emzingo to other business school students. Comments from participants over multiple programs identified Emzingo's NexGen program as “[the] highlight of my MBA...”, and "an experience I'll never forget...” Overall the participant feedback has been incredibly positive.

From the perspective of the social sector partners in South Africa, the real-world, experiential nature of the program is what really creates value. By having the students on-site over the course of six or more weeks, IE MBA participants have the chance to not only complete a meaningful project, but through their daily interactions, the students learn about cross-cultural communication, feel connected and part of the organization for which they are consulting, and have the opportunity 
to actually influence the internal culture of the organization. Emzingo Fellows have provided over 35,000 consulting hours. This hard work has paid off as $100 \%$ of partner organizations surveyed at the time of this research would recommend Emzingo. This is incredibly impressive considering the diversity of the partners. Figure 4 provides a summary of the types of field partners that Emzingo has been involved with.

The founder and current managing director of PUSH (Persevere Until Something Happens), an organization that deals with education, prevention and treatment of HIV/AIDS in Eldorado Park (about 25KM outside of Johannesburg), told one of Emzingo's co-founders that working with students from IE gave her more confidence as she began to better understand business principles and gained poise and self-assurance when talking to funders. This new-found confidence, she said, resulted in her ability to work effectively with government funders who in turn increased the organization's funding. Another founder and managing director of Nanga Vhutsilo, an organization that also works with children and adults impacted by HIV/AIDS, told Emzingo that "the students were very helpful and productive....and came for an internship, but became part of the family.” These types of relationships and the influence students have would not be possible without the benefits of an experiential learning program that allows the students to engage with partners while learning and applying skills acquired during the MBA. Emzingo has also seen increased demand from past partners and new organizations that wish to collaborate. As the nature of each project varies significantly and the social sector partners are quite different in size, structure, and organization type (NGO vs. for-profit), it is difficult to capture the same metrics across each project and partner. Emzingo has focused on ensuring that the work of the studentFellows is critical to the organization, immediately implementable, and designed to be achievable in a set period of time. The projects the students have produced consistently met these expectations 
and partners have benefited directly through increased funding, new partnerships, operations improvements, redesigned organizational structures, and more. A more anecdotal side benefit is the knowledge transfer between the students and organizations. In post-program debriefs, several Emzingo field partners identify the professional and business knowledge and acumen as benefits to the program. In addition to providing high caliber deliverables, students have consistently supported the personal and professional growth of the staff members at the social sector organizations and given the staff tools and knowledge that can be applied beyond the Emzingo project. Emzingo has found that by setting the expectation for all parties that the project will be co-created, all individuals can and will learn from each other, and that mutual success and understanding is core value, the odds of success are increased. And overall, each of Emzingo's stakeholders has been satisfied with the program outcomes.

\subsection{Contribution to the field}

The collaboration between IE and Emzingo has proven successful based on the overwhelmingly positive feedback from the participants and partner organizations. It is noteworthy to mention that this program is not only a success from the aforementioned points of view, but is consistent with the benefits of experiential learning. First, Emzingo created an environment where learning happens all the time, and also over time. It is a process, and learning will be defined by that process. By being embedded in an international context, the participants immediately can develop and build on their intercultural skills.

Secondly, the experiential learning program forces students to reflect on their own beliefs and ideas by placing them in challenging environments and making it impossible not to draw out those values, which are subsequently integrated into their value system and reflected in their behavior. Also, as part of this process, students work with a group of their peers as well as international 
clients. Conflict and disagreements inevitably surface and students have the opportunity to think about these situations, recognize emotions, and determine an appropriate course of action. This happens in part because of the differences in cultural backgrounds. The student teams need to interact and consult with a client that is international, requiring the students to build and enhance their intercultural skills. Additionally, the program Emzingo has designed results in an iterative process for the students, which consists of learning, applying, reflecting, adjusting, and constantly interacting with the local environment, as shown in the diagram below.

Finally, it becomes quite clear by the end of the program that participants go away with incredible memories of experiences (most likely more memorable than those of a traditional classroom experience) as well as knowledge and skills they build through this experiential learning process. Since these experiences are set in an international context, that really allows the students to build and enhance their intercultural skills. Figure 3 provides a visual summary of the Emzingo Model.

We interviewed Emzingo Fellows, the Emzingo staff, and partners in Johannesburg to identify various participant benefits after completing the NexGen Program. Almost unanimously all agreed that the participants have enhanced business and entrepreneurial skills, a deep understanding of the social sector and social entrepreneurship, have become more reflective, responsible, and selfaware leaders. Emzingo founders assert that the students who participate in the program are able to directly apply their business skills to tackle issues in the social arena, are better prepared to create sustainable business models, and understand the nature of an emerging market better than their peers due to the experiential learning aspect of the program. Throughout the program and various activities the students participate in, Emzingo ensures that the MBA students consider the business, social, environmental, and personal implications of business decisions and challenge the Fellows to leverage business principles for the benefit of social good through their project work. 
More than 300 students over the course of sixteen programs have now completed the Emzingo NexGen program. Participants saw myriad benefits from the program. Learning how to manage with limited resources (financial resources, human resources, skills of colleagues, and capacity of the organizations) while still creating a meaningful, high quality solution was the single most cited skill transferable to the business world.

Another often cited benefit is the opportunity to apply functional and systemic skills learned in the MBA to a real-world situation in an emerging market. For some, learning and applying consulting frameworks and skills in a completely new, international, and challenging environment was the most important development opportunity. For others, the development of client management and stakeholder engagement skills was most valuable. It is not uncommon to hear participants make comments like the one a recent participant made. She claimed that the experience, from a professional point of view, allowed her to "put into use marketing skills and develop a value proposition for the social enterprise's service” which will help her make a transition into a marketing role post-MBA.

Filling a gap in the literature, the Emzingo program provides MBA students an opportunity to develop as managers outside the classroom. It is important to go back and to link the experience of the Emzingo participants to the four-stage EL Model (Kolb and Kolb 2012). Again, the four stages for the model are Situation Analysis, Problem Analysis, Solution Analysis, and Implementation Analysis. First, the Emzingo experience allows participants to get out of their comfort zone to identify the problem. The participants rarely have experience in South Africa or the host country, so they have to work hard to understand the situation. Second, participants are working in a new country and a new industry as well as working with companies in the social 
sector. This requires the participants to really develop their skills since they really have to to identify the core of the problem that the client has.

The third stage of solution analysis is where the participants get to take their ideas and actually map out their solutions. They need to ensure that their solutions both work in the social sector and can be put in place in the country that they are working in. Since both of these are new environments for the learner, the experience pushes the learners' limits, allowing them to benefit even more for the experience and truly build on their learning through this experience. The Emzingo experience allows participants to truly experience the fourth stage of the EL model. Participants will need to make sure they interact with the client and their team to ensure that the solution they put in place is actually enacted. The client is from a different culture and also speaks a different "language" so to speak as the client is a social enterprise and might not relate to all of the business lexicon that the MBA's might be comfortable with. This also builds on the learner's intercultural skills, further building on a benefit of the experience.

Leadership, creative thinking, tolerance for ambiguity, and understanding [and willingness] to take calculated risks are very important concepts for managers to have, yet they are very difficult to teach (Kuratko, 2005). Yet, these are the skills that Emzingo develops. Many of our interviews specifically mentioned various leadership attributes that were developed through the program. The development of these entrepreneurship skills, specifically social entrepreneurship, would not have been possible without the experiential nature of this program.

For others, personal development and growth stood out as the most significant part of the experience. These participants noted that their new appreciation for cultural differences, significant improvements in emotional intelligence and self-awareness, and an understanding of what they are truly passionate about were positive outcomes from the experience. Again, this helps build to the 
extant literature by helping give an example of an opportunity that helps to build participants intercultural skills. Overall, IE and Emzingo are convinced that this type of experiential learning program is ideal for incorporating aspects of social entrepreneurship into the MBA curriculum.

\section{CONCLUSION}

In this paper, we provided an example of how experiential learning can be used to effectively incorporate social entrepreneurship into the MBA curriculum. With a well-designed experiential learning program, students have the opportunity to directly apply the knowledge and skills they have learned in business school, grow personally and professionally, and add value to society atlarge. Participants experience this program in an international context, which is designed into the program to enhance participants’ intercultural skills.

Overall, experiential learning is a useful tool and should be a strong component of entrepreneurial education (Tracey and Phillips, 2007). It is a core learning component in educating the next generation of students (James and Schmitz, 2011), and when considered in the context of business education, it is a way to leverage several of the methods Tracey and Phillips (2007) suggest in order to incorporate social entrepreneurship into the curricula.

This paper discussed the different ways that various MBA programs are introducing social entrepreneurship in their curricula. Social Entrepreneurship can be used to introduce managers to two very vital aspects of business practice that they would otherwise not experience in a typical MBA program. First, they are exposed to the social sector in the form of not-for-profits or social enterprises, and it also allows them to understand how this sector is different from the typical management systems that they are accustomed to. Second, they will also develop a better understanding of the social sector and how it impacts the economy. This will allow these future managers to better position their firms to create long-term business value. In the case study cited, 
this means benefit for the students, faculty, social sector partners, and academic institution. The benefits of introducing social entrepreneurship into the MBA curriculum will be realized by all of these parties, but in different ways.

Although we support the use of experiential learning, we must recognize that it does have some limitations. How will such programs be run? How will faculty be compensated for the extra time required to deal with these programs? How can program directors ensure that the students learn through such programs and how is the learning measured? We hope that this case study helps readers evaluate some of the benefits of experiential learning and provides them with a road map for implementing such programs at their organizations.

In this case study of the program between IE Business School and Emzingo, educating future managers through experiential learning was identified as a viable and valuable option for including social entrepreneurship into the MBA curriculum. Experiential learning is a very powerful tool with positive implications for its participants. Participants in experiential learning programs can provide management insights that are formed by understanding situations from various points of view and allows them to form educated opinions that consider multiple perspectives. We hope that the case study presented here demonstrates the value that educating future managers about social entrepreneurship through experiential learning adds to an MBA program. 
Table 1 - Social Entrepreneurship and Experiential Learning in the MBA

\begin{tabular}{|c|c|}
\hline $\begin{array}{c}\text { Tracey \& Phillips } 6 \text { Ways to Educate Social } \\
\text { Entrepreneurs }\end{array}$ & $\begin{array}{l}\text { Experiential Learning Activities for MBA } \\
\text { Programs }\end{array}$ \\
\hline Weave the topic into traditional courses & $\begin{array}{l}\text { - Develop simulations involving SE as part of } \\
\text { the curriculum } \\
\text { - As an elective course, create an } \\
\text { environment for students to incubate their } \\
\text { own social entrepreneurship idea }\end{array}$ \\
\hline \multicolumn{2}{|l|}{ Create a lecture series } \\
\hline Have students develop case studies & $\begin{array}{l}\text { - Have students develop case studies on } \\
\text { organizations they work with during } \\
\text { internships/consulting projects } \\
\text { - Assign case study development on local } \\
\text { organizations for whom students can } \\
\text { support voluntarily part-time }\end{array}$ \\
\hline Business Plans on SE & $\begin{array}{l}\text { - Perform field research and work part-time } \\
\text { during the academic year to develop plan }\end{array}$ \\
\hline Consulting projects on SE & $\begin{array}{l}\text { - Part-time during the academic year or } \\
\text { during the summer or winter break, provide } \\
\text { short-term consulting assignments for } \\
\text { students to work social entrepreneur }\end{array}$ \\
\hline Internships & $\begin{array}{l}\text { - Create a pipeline of summer internship } \\
\text { opportunities with social entrepreneurs }\end{array}$ \\
\hline
\end{tabular}

(adapted from Tracey \& Phillips (2007)

Table 2 - Emzingo Stakeholder Benefits Matrix

\begin{tabular}{cll}
\hline Stakeholder & \multicolumn{1}{c}{ Program Benefits } \\
\hline Student Participant & , $\begin{array}{l}\text { Provide a real world application, in a challenging environment, of the skills } \\
\text { learned in the academic program }\end{array}$ \\
& Allow students to have a positive impact, and provide exposure to social \\
innovation and entrepreneurship in a different cultural context & Offer a practical experience that enhances students' employment \\
opportunities & Connect and network students amongst each other, forming linkages for \\
& shared knowledge and continued learning
\end{tabular}


Figure 1 - CSR Grouping

\section{Details of Three Phases of Program}

\section{Orientation}

- 5- 7 days, 6-10 hours per day in Madrid, Spain or Emerging Market

- Cultural and project preparation

- Pre-work and teambuilding

\section{Immersion and Core Project}

- 6-week immersion in South Africa, Peru, or Brazil

- Social sector consulting project

- 70+ hours of leadership development curriculum

\section{Virtual Project}

- 2-weeks virtual work

- Apply skills from previous 6 weeks

- Follow up on Personal Development Plan

Figure 2 - Emzingo Stakeholder Responsibilities

\section{Academic Partner}

- Administrative activities

- Financial support

- Faculty involvement

- Promotion/marketing

- Elective credit to students

Social Sector Partners

- Leadership support

- Financial contribution

- Implementation of activities during program and after projects are completed

\section{Students (Fellows)}

- Pro-bono consulting

- Academic deliverables

- Post-program presentation

to university audience

\section{NexGen}

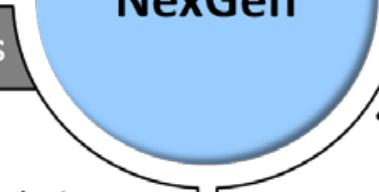

$\overbrace{-1+n}$

- Curriculum design and facilitation

- Project sourcing/development

- Logistics and operations

- Mentoring/coaching 
Figure 3 - Emzingo’s Learning Model and Components

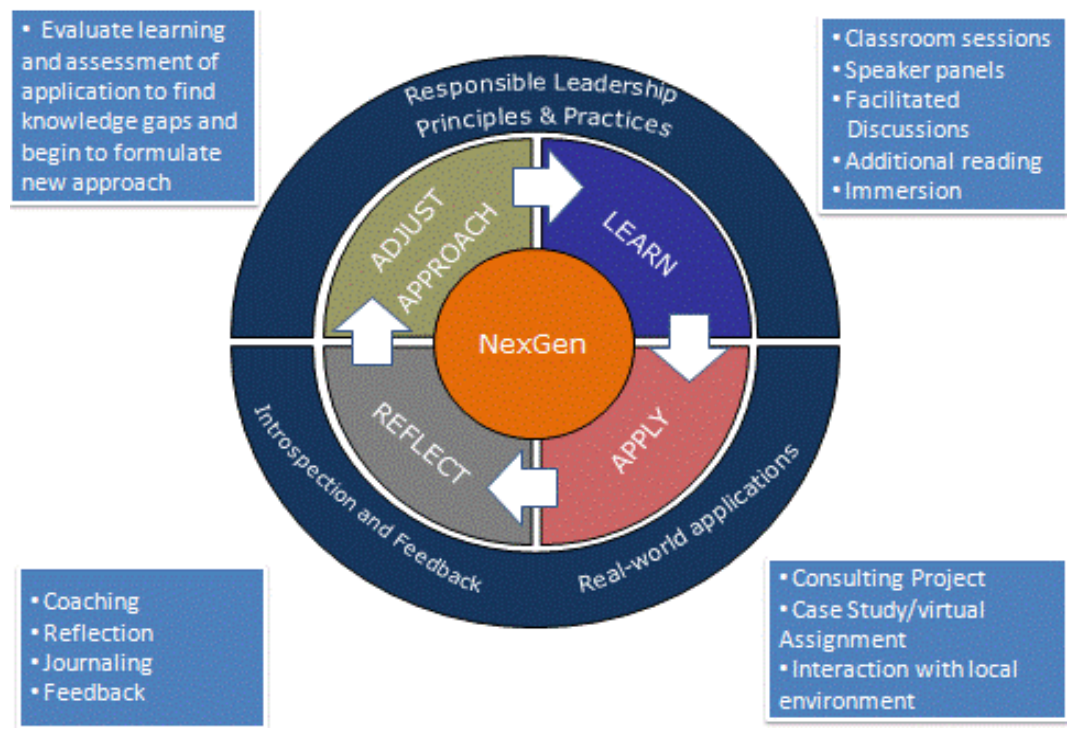

Figure 4 - Partners

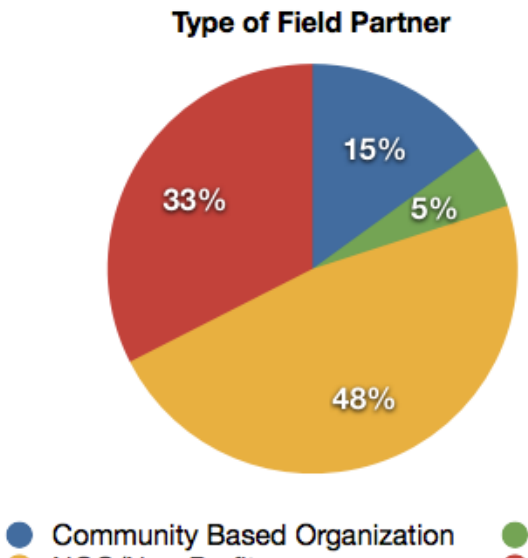

NGO/Non-Profit
Which Millenium Development Goals our Field Partners are tackling...

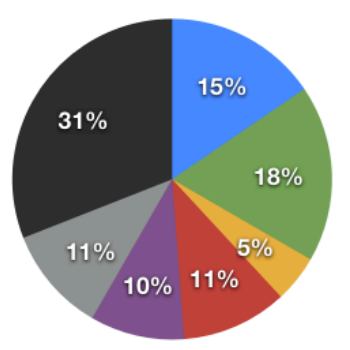

Poverty and Hunger

Education

Gender Equality

Health

HIV/Aids

Environmental Sustainability/Conservation

- Economic Development 
Ethical approval: All procedures performed in studies involving human participants were in accordance with the ethical standards of the institutional and/or national research committee and with the 1964 Helsinki declaration and its later amendments or comparable ethical standards.

Informed consent: Informed consent was obtained from all individual participants included in the study.

\section{References}

AACSB (Association to Advance Collegiate Schools of Business). (2016). 2016 Business School Data Guide. Tampa, Florida, USA. Available: http://www.aacsb.edu/-/media/aacsb/publications/datatrends-booklet/2016.ashx?la=en.

AACSB (Association to Advance Collegiate Schools of Business). (2010). Business School Data Trends and 2010 List of Accredited Schools. Report posted in 2010 on AACSB, Tampa, Florida, USA. Available: http://www.aacsb.edu/publications/businesseducation/2010-Data-Trends.pdf.

Ashoka. (2012). Social Entrepreneur. Retrieved 18 November 2012 from https://www.ashoka.org/social_entrepreneur.

Aspen Institute Center for Education. (2009). A Closer Look at Business Education: Sustainability in the

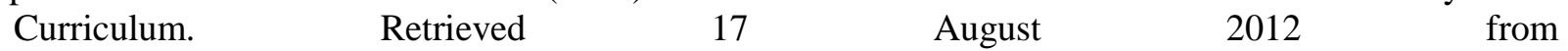
http://www.aspencbe.org/documents/SustainabilityintheCurriculum.pdf.

Bedwell, W. L., Fiore, S. M., \& Salas, E. (2014). Developing the future workforce: An approach for integrating interpersonal skills into the MBA classroom. Academy of Management Learning \& Education, 13(2), 171-186.

Beard, C. M. \& Wilson, J.P. (2002). The power of experiential learning: a handbook for trainers and educators. Kogan Page: London.

Bennis, W.G. \& O’Toole, J. (2005). How business schools lost their way. Harvard Business Review, 83(5): 96-104.

Blackman, S. (2011). Social Entrepreneurship and M.B.A. Retrieved 24 August 2011 from http://www.usnews.com/education/blogs/MBA-admissions-strictly-business/2011/08/12/socialentrepreneurship-and-the-mba.

Boud, D., Cohen, R., \& Walker, D. (1993). Using Experience for Learning. Society for Research into Higher Education and Open University Press: 1-17.

Byrne, J. A. (2010). Social Entrepreneurship: The Best Schools and Programs. Retrieved 8 August 2011 from http://poetsandquants.com/2010/08/13/social-entrepreneurship-the-best-schools-programs/.

Charleston, B., Gajewska-De Mattos, H., \& Chapman, M. (2017). Cross-cultural competence in the context of NGOs: bridging the gap between 'knowing' and 'doing'. The International Journal of Human Resource Management, 1-25.

Columbia University Graduate School of Business (2011). Electives. Retrieved 15 June 2011 from http://www4.gsb.columbia.edu/mba/academics/curriculum/electives.

Dewey, J. (1938). Education and Experience. New York: Simon and Schuster.

Duke Univesity (2011). Duke Center for Advancement of Social Entrepreneurship. Retrieved 6 June 2011 from http://www.caseatduke.org/about/. 
Eberhardt, B.J., Moser, S. \& McGee, P. (1997). Business concerns regarding MBA education: effects on recruiting. Journal of Education for Business. 72: 293-296

Economist, The. (2012). B Corps - Firms with benefits. A new sort of caring, sharing company gathers momentum. January $\left(7^{\text {th }}-13^{\text {th }}\right) 2012$.

Financial Times. (2017). 2017 Global MBA Rankings. Retrieved 20 February 2017 from http://rankings.ft.com/businessschoolrankings/global-mba-ranking-2017.

Gannon, J., Rodrigo, Z., \& Santomà, R. (2016). Learning to work interculturally and virtually: Developing postgraduate hospitality management students across international HE institutions. The International Journal of Management Education, 14(1), 18-27.

Gentry, J. W. (1990). Guide to business gaming and experiential learning. New York: Nichols Pub Co.

Harvard Crimson, The. (2009). HBS Students Take Ethics Oath. Retrieved 19 November 2012 from http://www.thecrimson.com/article/2009/6/2/hbs-students-take-ethics-oath-as/

Honig, B. (2004). Entrepreneurship Education: Toward a Model of Contingency-Based Business Planning. Academy of Management Learning \& Education, 3: 263.

James, C.D. \& Schmitz, L.J. (2011). Transforming Sustainability Education: Ethics, Leadership, Community Engagement, and Social Entrepreneurship. International Journal of Business and Science, 2(5): 1-7.

Jones, R. (2011). More business schools embracing do-gooders. Retrieved 2 August 2011 from http://www.msnbc.msn.com/id/40589291/ns/business.

Kegan, Robert, (1994). In Over Our Heads, The Mental Demands of Modern Life. Harvard University Press: Cambridge, MA.

Kolb, David A. "Management and the learning process." California management review 18.3 (1976): 2131.

Kolb, D.A., (1984). Experiential Learning: Experience as the source of learning development. Englewood Cliffs: Prentice-Hall.

Kolb, A. Y. \& Kolb, D. A. (2005). Learning Styles and Learning Experiences: Enhancing Experiential Learning in Higher Education. Academy of Management Learning \& Education, 4(2): 193-212.

Kolb, Alice Y., and David A. Kolb. "Experiential learning theory." Encyclopedia of the Sciences of Learning. Springer US, 2012. 1215-1219.

Khurana, R. (2007). From higher aims to hired hands: The social transformation of American business schools and the unfulfilled promise of management as a profession. Princeton, NJ: Princeton University Press. 4

Kuratko, D.F. (2005). The Emergence of Entrepreneurship Education: Development, Trends, and Challenges. Entrepreneurship Theory and Practice. 29(5) 577-598.

Lawrence, T. B., Phillips, N., \& Tracey, P. (2011). Academy of Management Learning \& Education. Retrieved on 25 July 2011 from http://aom.pace.edu/amle/2012SI_CFP.asp.

Mair, J. \& Marti, I. (2006). Social entrepreneurship research: A source of explanation, prediction, and delight. Journal of World Business. 41: 36-44.

Marsh, C. (2013). Business executives' perceptions of ethical leadership and its development. Journal of Business Ethics, 114(3), 565-582.

Martin, R. and Osberg, S. (2007). Social Entrepreneurship: The Case for Definition. Stanford Social Innovation Review. p. 13. 
McLean, M. \& Peredo, A.M., (2006). Social Entrepreneurship: A critical review of the concept. Journal of World Business, 41: 56-65.

Mintzberg, H. (2004). Managers, not MBAs: A hard look at the soft practice of managing and management development. San Francisco, CA. Berrett-Koehler Publishers.

Mintzberg, H., and Lampel, J. (2001) "MBAs as CEOs." www.henrymintzberg.com

Net Impact. 2012. Talent Report: What Workers Want in 2012 (2012) |Executive Summary. Retrieved 19 August 2012 from http://netimpact.org/docs/publications-

docs/NetImpact_WhatWorkersWant2012.pdf.

Olszak, L. M. \& Sidorick, M.S. (2003). A study of social enterprise training and support models. Report published in 2003 by Olszak Management Consulting. Available:

http://www.austincc.edu/npo/library/documents/Study\%20of\%20Social\%20Entreprise\%20Training\%2 0And\%20Support.pdf.

Pfeffer, J. \& Fong, C. (2002). The end of business schools? Less success than meets the eye. Academy of Management Learning and Education, 1(1): 78-95.

Phills, J. (2008). Why Social Innovation is the best vehicle for understanding and creating social change. Stanford Social Innovation Review. 6(4): 34.

Pomerantz, M. (2003). The business of social entrepreneurship in a "down economy". In Business Magazine, March/April 2003, p. 25.

Porter, M. E. \& Kramer, M. R. (2006). Strategy and Society The Link between Corporate Social Responsibility and Competitive Advantage. Harvard Business Review, December 2006: 78-91.

Porter, M. E. \& Kramer, M. R. (2011). Creating Shared Value - How to reinvent capitalism-and unleash a wave of innovation and growth. Harvard Business Review, January-February 2011: 1-17.

Ramlall, S. J., \& Ramlall, D. P. (2016). An Effective MBA: Perspectives of Students, Faculty, and Employers. Journal of Management and Strategy, 7(3), 18.

Rashford, N. S. \& Neiva de Figueiredo, J. (2010). The "Live Case" Intervention Method: Leadership Skills Through Experiential Learning. Retrieved from the Academy of Management Annual Proceedings, Academy of Management.

Stevens, Harry (2011). 5 Great MBA Programs for Social Entrepreneurship. Retrieved 11 September 2011 from http://www.justmeans.com/5-Great-MBA-Programs-for-Social-Entrepreneurship/26644.html

Singh, A. \& Wise, C. (2010). Jobs Are Out There for Sustainable MBA Grads if They're Willing to Do the Work. Retrieved March 12, 2010 from_http://vaultcareers.wordpress.com/2010/03/12/jobs-are-outthere-for-sustainable-mba-grads-if-theyre-willing-to-do-the-work/.

Sullivan, L. (2011). MBA Students \& Social Entrepreneurship: A Trend Toward A Degree In Doing Good. Retrieved 8 August 2011 from http://www.huffingtonpost.com/2011/01/02/mba-program-socialentrepreneurship_n_802729.html .

Taras, V., Caprar, D. V., Rottig, D., Sarala, R. M., Zakaria, N., Zhao, F., ... \& Bryła, P. (2013). A global classroom? Evaluating the effectiveness of global virtual collaboration as a teaching tool in management education. Academy of Management Learning \& Education, 12(3), 414-435.

Tuleja, E. A. (2008). Aspects of intercultural awareness through an MBA study abroad program: Going “Backstage”. Business Communication Quarterly, 71(3), 314-337.

Tracey, P. \& Phillips, N. (2007). The Distinctive Challenge of Educating Social Entrepreneurs: A Postscript and Rejoinder to the Special Issue on Entrepreneurship Education. Academy of Management Learning \& Education 6(2): 264-271. 
Yamazaki, Y. \& Kayes, D. C. (2004). An Experiential Approach to Cross Cultural Learning: A review and integration of competencies for successful expatriate adaptation. Academy of Management Learning \& Education 3(4): 362-379.

Yin, R. (2009). Case Study Research Design and Methods. Sage Publications, Inc.: Thousand Oaks, CA. 
Appendix 1

\begin{tabular}{|c|c|c|c|c|c|}
\hline Ranking & School & Social Entrepreneurship Programs \& Activities w/ Description & $\begin{array}{l}\text { Elective Courses in Social } \\
\text { Entrepreneurship/Social Innovation }\end{array}$ & Experiential Learning & Country \\
\hline 1 & $\begin{array}{l}\text { London Business } \\
\text { School }\end{array}$ & $\begin{array}{l}\text { The Global Social Venture Competition - Through a partnership with Haas School of } \\
\text { Business at Berkeley and Columbia Business School, it provides an opportunity for teams } \\
\text { to compete for over } \$ 70 \mathrm{~K} \text { in prizes that are awarded to teams who have the best blend of } \\
\text { social and economic returns built into their idea/model. }\end{array}$ & \begin{tabular}{|l|} 
- The New Revolution: Social \\
Entrepreneurship in the 21st Century \\
- Entrepreneurship in Emerging markets
\end{tabular} & \begin{tabular}{|l|} 
- London Business Experiences Program \\
-Global Business Experiences Program \\
- Case studies and volunteer projects
\end{tabular} & United Kingdom \\
\hline 1 & $\begin{array}{l}\text { University of } \\
\text { Pennsylvania: } \\
\text { Wharton }\end{array}$ & $\begin{array}{l}\text { Wharton Social Venture Fund - Student run organization that seeks to provide support } \\
\text { and resources to critical initiatives by partnering with venture capitalists who focus on } \\
\text { triple bottom line investing. } \\
\text { Wharton International Volunteer Program - Provides students the opportunity to travel } \\
\text { abroad and apply their business skills in a setting that helps improve the quality of life and } \\
\text { economic development in developing countries. } \\
\begin{array}{l}\text { Wharton Non-profit Board Leadership Program - Gives students an experiential learning } \\
\text { opportunity to learn how their skills can support the non-profit sector through interaction } \\
\text { with local organizations }\end{array}\end{array}$ & $\begin{array}{l}\text { - Global Immersion Program } \\
\text { - Microfinance } \\
\text { - Community reinvestment } \\
\text { - Entrepreneurship and Social Wealth } \\
\text { Creation } \\
\\
\end{array}$ & $\begin{array}{l}\text { - The Wharton Leadership Program } \\
\text { - Global Immersion Program } \\
\text { - Global Consulting Practicum } \\
\text { - Nonprofit Board Leadership Program } \\
\text { - Leadership Ventures }\end{array}$ & United States \\
\hline 3 & $\begin{array}{l}\text { Harvard Business } \\
\text { School }\end{array}$ & $\begin{array}{l}\text { Social Enterprise Initiative - Works to apply innovative business practices and managerial } \\
\text { disciplines to drive high-impact social change through engagement with the social sector, } \\
\text { coursework, and career development opportunities } \\
\text { Independent Project in social enterprise - Students work on a project of strategic } \\
\text { importance to partner organization with social impact } \\
\text { Horace W. Goldsmith Fellowship - Provides grants to 7-10 first year MBA students who } \\
\text { have shown leadership and commitment to working in the social sector. }\end{array}$ & \begin{tabular}{|l|} 
- Incorporate social enterprise case \\
studies into various courses \\
- Business at the Base of the Pyramid \\
- Entrepreneurship in Education \\
Reform \\
- Entrepreneurship in the Private and \\
Social Sectors \\
- Leading and Governing High \\
Performing Nonprofit Organizations \\
- Social Entrepreneurship in the \\
Business Sector \\
- Social Impact Investing: Field Course
\end{tabular} & $\begin{array}{l}\text { - Immersion Experience Program(IXP) } \\
\text { - Field Base Learning projects/electives }\end{array}$ & United States \\
\hline 4 & INSEAD & $\begin{array}{l}\text { Insead Social Innovation Centre - Used as a platform for research and engagement in the } \\
\text { area of social innovation } \\
\text { INSEAD Social Entrepreneurship Catalyst Programme - Through events, workshops, } \\
\text { networking opportunities, and projects, the programme aims to allow students to } \\
\text { understand social entrepreneurship, expand their potential for impact, and act effectively } \\
\text { on their social entrepreneurship interests and passions. }\end{array}$ & $\begin{array}{l}\text { - Entrepreneurial Strategies in } \\
\text { Emerging Markets } \\
\text { - Strategic Corporate Social } \\
\text { Responsibility }\end{array}$ & - Entrepreneurship Boot camp & France/Singapore \\
\hline 4 & $\begin{array}{l}\text { Stanford University } \\
\text { GSB }\end{array}$ & $\begin{array}{l}\text { Center for Social Innovation - It has a purpose to "build and strengthen the capacity of } \\
\text { individuals and organizations to develop innovative solutions to social problems" } \\
\text { Certificate of Public Management and Social Innovation - By focusing their electives and } \\
\text { extra curricular activities around these topics, students can received this certification in } \\
\text { addition to MBA } \\
\text { Social Innovation Fellowship - An opportunity to obtain } \$ 80-100 \mathrm{~K} \text { to start a social } \\
\text { purpose organization } \\
\begin{array}{l}\text { Stanford Management Internship Fund - Provides financial supports students who take } \\
\text { internships in nonprofits, governments and social purpose businesses }\end{array}\end{array}$ & \begin{tabular}{|l|} 
- Social Entrepreneurship \\
- Strategic Management of Non-Profits \\
- The Power of Social Technology \\
- Entrepreneurial Design for Extreme \\
Affordability
\end{tabular} & $\begin{array}{l}\text { - Global Management Immersion } \\
\text { Experience (GMIX) } \\
\text { - Service Learning Trips } \\
\text { - Healthcare Treks } \\
\text { - Independent Studies }\end{array}$ & United States \\
\hline
\end{tabular}




\begin{tabular}{|c|c|c|c|c|c|}
\hline Ranking & School & Social Entrepreneurship Programs \& Activities w/ Description & \begin{tabular}{|l|} 
Elective Courses in Social \\
Entrepreneurship/Social Innovation
\end{tabular} & Experiential Learning & Country \\
\hline 6 & \begin{tabular}{|l|} 
Hong Kong UST \\
Business School
\end{tabular} & $\begin{array}{l}\text { Hong Kong Social Enterprise Challenge - A social venture business plan competition } \\
\text { hosted by Hong Kong UST. }\end{array}$ & None & - Information not available & China \\
\hline 7 & $\begin{array}{l}\text { Columbia Business } \\
\text { School }\end{array}$ & $\begin{array}{l}\text { The Social Enterprise Program - Offers a variety of classroom and extracurricular activities } \\
\text { with the objective to advance the understanding of how management can contribute to } \\
\text { society and the environment and to develop the next generation of social enterprise } \\
\text { leaders. } \\
\text { Social Enterprise Summer Fellowship - Student run initiative that raises funds to help MBA } \\
\text { students work in the US or abroad social enterprises. } \\
\text { Nonprofit Board Leadership Program - Includes training sessions, board interaction, and a } \\
\text { project to help students understand how nonprofit boards operate and contribute } \\
\text { business insights to the organizations they work with. }\end{array}$ & \begin{tabular}{|l|} 
- The Private Sector and International \\
Development \\
- Business in Society: Doing Well by \\
Doing Good? \\
- Global Marketing Consulting for \\
Social Enterprise \\
- Business Innovations in International \\
Development \\
\end{tabular} & \begin{tabular}{|l|} 
- International Development Consulting \\
Project Travel Fund \\
- Small Business Consulting Program \\
- International Development Club projects \\
- Local volunteering opportunities \\
\end{tabular} & United States \\
\hline 8 & IE Business School & $\begin{array}{l}\text { Emzingo NexGen program partnership - A hybrid leadership development and social } \\
\text { impact program that allows students the opportunity to apply business skills in the social } \\
\text { sector. } \\
\text { Social Impact Management - Platform that allows for knowledge sharing interaction among } \\
\text { students, faculty and alumni on social sector topics. }\end{array}$ & $\begin{array}{l}\text { - Social Venture Lab } \\
\text { - Sustainable Development and CSR } \\
\text { - Social Entrepreneurship } \\
\\
\end{array}$ & \begin{tabular}{|l|} 
- Emzingo NexGen Program \\
- Global Consulting Practicum \\
- IECP (IE Consulting Project)
\end{tabular} & Spain \\
\hline 9 & Iese Business School & \begin{tabular}{|l|} 
CBS - Center for Business in Society - Promotes social responsibility and sustainable \\
development in businesses. \\
Annual Forum on Business and Sustainable Development and other conferences \\
including Base of the Pyramid Learning Lab and "Doing Well and Doing Good": A \\
Conference on Responsible Business. \\
\end{tabular} & $\begin{array}{l}\text { - Social Entrepreneurship } \\
\text { - Current Social and Political Ideas for } \\
\text { Business } \\
\text { - Management of Nonprofit } \\
\text { Institutions } \\
\text { - The Base of the Pyramid and } \\
\text { Sustainable Growth } \\
\text { - Tools and Strategies for Sustainable } \\
\text { Business }\end{array}$ & - Information not available & Spain \\
\hline 9 & \begin{tabular}{|l|} 
MIT Sloan School of \\
Management
\end{tabular} & $\begin{array}{l}\text { MIT Sloan Social Impact Fellowship - Provides support for students to take on important } \\
\text { societal challenges during their internship. } \\
\text { Sloan Entrepreneurs for International Development - Action learning projects are designed } \\
\text { for students to work on entrepreneurship and international development related projects. } \\
\text { Lab opportunities - There are several "Labs" that provide students the opportunity to } \\
\text { work with organizations virtually and in person. Students have the opportunity to work in } \\
\text { a variety of areas, including some organizations in social entrepreneurship. }\end{array}$ & \begin{tabular}{|l|} 
- Social Entrepreneurship \\
- Leading Profound Innovation for a \\
More Sustainable World \\
- Developmental Entrepreneurship \\
- Strategic Management for Nonprofits \\
\end{tabular} & $\begin{array}{l}\text { - China Lab } \\
\text { - Entrepreneurship Lab } \\
\text { - Global Entrepreneurship Lab } \\
\text { - Global Health Delivery Lab } \\
\text { - India Lab } \\
\text { - Leadership Lab } \\
\text { - Sustainable Business Lab } \\
\text { - Finance Research Practicum \& } \\
\text { Proseminars }\end{array}$ & United States \\
\hline
\end{tabular}




\begin{tabular}{|c|c|c|c|c|c|}
\hline Ranking & School & Social Entrepreneurship Programs \& Activities w/ Description & \begin{tabular}{|l|} 
Eective Courses in Social \\
Entrepreneurship/Social Innovation
\end{tabular} & Experiential Learning & Country \\
\hline 11 & $\begin{array}{l}\text { Indian Institute of } \\
\text { Management } \\
\text { Ahmedabad } \\
\end{array}$ & $\begin{array}{l}\text { Claim to address social issues through activities within other organizations such as: } \\
\text { The Ravi Matthai Center for Educational Innovation, The Center for Innovation, } \\
\text { Incubation, and Entrepreneurship, and The Center for Management of Health Services. }\end{array}$ & Information not publicly available & $\begin{array}{l}\text { - International Immersion weeks } \\
\text { - Capstone projects } \\
\text { - Individual Research Study } \\
\end{array}$ & India \\
\hline 12 & $\begin{array}{l}\text { University of } \\
\text { Chicago: Booth }\end{array}$ & $\begin{array}{l}\text { Social Entrepreneurship Lab - Students work with local nonprofit and for-profit enterprises } \\
\text { that have social missions. } \\
\text { Service Corps - Students consult to local nonprofit organizations. }\end{array}$ & Information not publicly available & $\begin{array}{l}\text { - Management, New Venture, Private } \\
\text { Equity \& Venture Capital, Social } \\
\text { Entrepreneurship and Clean Tech labs } \\
\text { - LEAD (Leadership Effectiveness and } \\
\text { Development) } \\
\end{array}$ & United States \\
\hline 13 & $\begin{array}{l}\text { Indian School of } \\
\text { Business }\end{array}$ & $\begin{array}{l}\text { Social Entrepreneurship Forum with Khemka Foundation - Serves as a dynamic hub of } \\
\text { thought leadership, linkages and robust solutions exchange and over time strengthen the } \\
\text { ecosystem of social entrepreneurship. } \\
\text { Centre for Emerging Market Solutions - act as a lab where market-based solutions to } \\
\text { emerging market problems are developed and then ported to other emerging markets. } \\
\text { The Global Social Venture Competition Asia-Africa - Provides an opportunity for teams to } \\
\text { compete for over \$70K in prizes that are awarded to teams who have the best blend of } \\
\text { social and economic returns built into their idea/model. } \\
\text { iDiya - Social Venture Ideas Competition that aims to stimulate, enable and develop high- } \\
\text { impact, self sustaining social businesses in India. }\end{array}$ & $\begin{array}{l}\text { - Sustainable Business Operations: } \\
\text { Value Creation and Environmental } \\
\text { Considerations }\end{array}$ & $\begin{array}{l}\text { - Experiential Learning Program } \\
\text { - Global Consulting Practicum }\end{array}$ & India \\
\hline 14 & IMD & $\begin{array}{l}\text { IMD Social Responsibility Scholar - Scholarship given to a student who was previously } \\
\text { working as a social entrepreneur or for an NGO prior to business school. }\end{array}$ & $\begin{array}{l}\text { - Economic, environmental and social } \\
\text { sustainability }\end{array}$ & $\begin{array}{l}\text { - Start-up Projects } \\
\text { - Discovery Expedition } \\
\text { - International Consulting Projects } \\
\end{array}$ & Switzerland \\
\hline 15 & $\begin{array}{l}\text { New York University: } \\
\text { Stern }\end{array}$ & $\begin{array}{l}\text { NYU Reynolds Program in Social Entrepreneurship - Each year, Stern undergraduate } \\
\text { sophomores apply for a coveted Scholars spot in the NYU Reynolds Program in Social } \\
\text { Entrepreneurship. } \\
\text { International Social Impact Strategies - Students travel to India during winter break and } \\
\text { gives students hands-on exposure to the entrepreneurial pursuit of social impact in } \\
\text { developing economies. } \\
\text { Berkley Center for Entrepreneurship and Innovation - Includes a social venture } \\
\text { competition, annual conference on social entrepreneurship, and social entrepreneur of the } \\
\text { year award. }\end{array}$ & \begin{tabular}{|l|} 
- Examining the Nonprofit Capital \\
Market \\
- Foundations of Social \\
Entrepreneurship \\
- Global Poverty Alleviation \\
- Introduction to Environmental and \\
Social Sustainability \\
- Investing in Microfinance \\
- International Social Impact Strategies: \\
India \\
- Social Venture Capital \\
\end{tabular} & $\begin{array}{l}\text { - Stern Consulting Corps } \\
\text { - Board Fellows Program } \\
\text { - Social Impact Internship Fund }\end{array}$ & United States \\
\hline
\end{tabular}




\begin{tabular}{|c|c|c|c|c|c|}
\hline Ranking & School & Social Entrepreneurship Programs \& Activities w/ Description & \begin{tabular}{|l|} 
Elective Courses in Social \\
Entrepreneurship/Social Innovation
\end{tabular} & Experiential Learning & Country \\
\hline 15 & $\begin{array}{l}\text { Yale School of } \\
\text { Management }\end{array}$ & $\begin{array}{l}\text { Program on Social Enterprise - Supports scholars, students, alumni, and practitioners } \\
\text { interested in exploring the ways in which business skills and market disciplines can be } \\
\text { harnessed to most effectively and efficiently achieve social objectives. }\end{array}$ & $\begin{array}{l}\text { - Global Social Entrepreneurship } \\
\text { - Global Social Enterprise } \\
\text { - Microfinance and International } \\
\text { Development }\end{array}$ & $\begin{array}{l}\text { - International Experience trips } \\
\text { - Web-based "raw" cases } \\
\text { - }\end{array}$ & United States \\
\hline 17 & Ceibs & $\begin{array}{l}\text { Social Entrepreneurship Business Competition - Business plan competition for RMB30,000 } \\
\text { cash prize. } \\
\text { Being Globally Responsible Conference - Brings together MBA students in Asia-Pacific } \\
\text { region. One of the focus areas is to help students learn how to establish a career path that } \\
\text { seamlessly combines genuine social contribution with profit generation. }\end{array}$ & None & - Information not available & China \\
\hline 18 & \begin{tabular}{|l} 
Dartmouth College: \\
Tuck
\end{tabular} & $\begin{array}{l}\text { Allwin Initiative for Corporate Citizenship - Aims to prepare Tuck students for leadership } \\
\text { in this increasingly complex, interconnected world. Works to ensure that the changing } \\
\text { issues at the intersection of business and society are a key component of MBA education } \\
\text { and includes social entrepreneurship. }\end{array}$ & $\begin{array}{l}\text { - Entrepreneurship in the Social Sector } \\
\text { - Business Strategies for Sustainability } \\
\text { - Business-Social Sector Partnerships }\end{array}$ & \begin{tabular}{|l|} 
- Independent Studies \\
- Tuck Global Consultancy
\end{tabular} & United States \\
\hline 18 & HEC Paris & $\begin{array}{l}\text { MAP - Mission and Action Project : An opportunity to work towards a humanitarian goal, } \\
\text { engage in fieldwork, sharpen business skills while aiding the community. } \\
\text { Social Business / Enterprise and Poverty Certificate - Additional, optional certification that } \\
\text { aims to train a new generation of managers, who are aware of societal challenges and who } \\
\text { aspire to be part of the solution, regardless of their professional activity. }\end{array}$ & None & $\begin{array}{l}\text { - Off Campus Leadership Seminar } \\
\text { - The MBA Tournament } \\
\text { - }\end{array}$ & France \\
\hline 20 & $\begin{array}{l}\text { Duke University: } \\
\text { Fuqua }\end{array}$ & $\begin{array}{l}\text { Concentration in Social Entrepreneurship - Optional Concentration for MBA students who } \\
\text { want to focus on business and social impact. } \\
\\
\text { Center for the Advancement of Social Entrepreneurship - A research and education center } \\
\text { promotes the entrepreneurial pursuit of social impact through the thoughtful adaptation of } \\
\text { business expertise. } \\
\text { Global Consulting Practicum- Students work with social enterprises and businesses } \\
\text { serving base-of-the-pyramid markets in developing economies. }\end{array}$ & $\begin{array}{l}\text { - Social Entrepreneurship } \\
\text { - Advanced Seminar in Social } \\
\text { Entrepreneurship } \\
\text { - Communities \& Development: Social } \\
\text { Capital, Entrepreneurship, and External } \\
\text { Support }\end{array}$ & $\begin{array}{l}\text { - Mentored Study Projects } \\
\text { - Fuqua On Board } \\
\text { - Duke Start-up Challenge } \\
\text { - Duke Program for Entrepreneurs }\end{array}$ & United States \\
\hline
\end{tabular}

